\title{
The Recent fire history of the Table Mountain National PARK AND IMPLiCATIONS FOR FIRE MANAGEMENT
}

\author{
GREG G. FORSYTH \\ BRIAN W. VAN WILGEN \\ Centre for Invasion Biology \\ CSIR Natural Resources and the Environment \\ South Africa \\ Correspondence to: Brian W. van Wilgen \\ e-mail: bvwilgen@csir.co.za \\ Postal Address: Centre for Invasion Biology, CSIR Natural Resources and the Environment, P.O. Box 320, Stellenbosch, 7599, South Africa.
}

\begin{abstract}
This paper provides an assessment of fire regimes in the Table Mountain National Park over the past four decades. We compiled a GIS database of all fires between 1970 and 2007 and analysed the fire regime in terms of the frequency, season and size of fires and the relationship between fire occurrence and fire weather. Most fires (90.5\% of area burnt) occurred in summer and autumn, the ecologically acceptable season for fires. However, mean fire return intervals declined by 18.1 years, from 31.6 to 13.5 years, between the first and last decades of the record respectively. The area subjected to short ( $\leq$ six years) intervals between fires covered $>16 \%$ of the park in the last two decades of the record, compared to $\sim 4 \%$ in the first two decades. A relatively small number of large fires dominated in terms of area burnt. Of the 373 fires recorded, 40 fires $>300$ ha burnt $75 \%$ of the area, while 216 fires $<25$ ha burnt $3.4 \%$ of the area. Fires occurred under a wide range of weather conditions, but large fires were restricted to periods of high fire danger. Prescribed burning was a relatively unimportant cause of fires, and most $(>85 \%)$ of the area burnt in wildfires. Areas subjected to short fire return intervals should be considered for management interventions. These could include the re-establishment of extirpated fire-sensitive species, the clearing of invasive alien plants and increased precautions for the prevention or rapid suppression of future accidental fires.
\end{abstract}

Keywords: Cape Floral Kingdom, fire weather, fynbos, ignitions, invasive alien plants

The Table Mountain National Park is a rugged $265 \mathrm{~km}^{2}$ area surrounded by the city of Cape Town, South Africa. It obtained World Heritage Site status in line with its global importance as a hotspot of biodiversity for higher plants and invertebrates (Cowling, Macdonald \& Simmons 1996). The dominant vegetation of the area is fynbos, a Mediterranean-climate shrubland that is both fire prone and fire adapted (Van Wilgen, Bond \& Richardson 1992, Van Wilgen, Richardson, Kruger \& Van Hensbergen 1992). The park is home to 2285 plant species, of which 90 are endemic. The park was proclaimed in 1998, prior to which it was managed by 14 separate public bodies; as a result, the earlier conservation management of the area was uncoordinated and fragmented (Van Wilgen 1996). Prior to proclamation as a national park, the area's unique biodiversity faced numerous threats, including inappropriate fire regimes arising from a lack of clear fire management policies (Richardson et al. 1996). One of the major aims of consolidating land parcels into a single conservation area was to promote a coordinated approach to fire management (Van Wilgen 1996).

The current fire management policy of the park is flexible (Forsyth et al. 2000). It recognises the need for periodic fire as an important ecological process and that prescribed fire will be needed from time to time. It also recognises that some wildfires are inevitable and that these should be taken into account by adjusting prescribed burning schedules as fire patterns develop. Fire management in the park is complicated by an extensive urban-wildland boundary. This means that houses and other property are at risk from wildfires and that fire suppression for nonecological reasons will be needed from time to time. It also means that prescribed fires need to be planned and conducted carefully to avoid the risk of damage. Widespread alien plant invasions bring added requirements in terms of fire management; these plants (dominated by trees and shrubs) are spread by fire and require careful treatment prior to burning (Richardson et al. 1994). Good conservation practice includes both the use of prescribed burning and allowing wildfires to burn in areas where they will do no ecological harm. However, the use of these approaches in close proximity to densely populated areas invites criticism, and managers need good information on past fires to support their actions. In addition, densely settled areas bring increased risks of unwanted ignitions. Managers need to be able to identify areas that would be at risk if such fires occurred, so that these areas could be afforded additional protection.

Future fire management actions within the park will be based on the assessment of fire records. Such assessments should identify areas where biodiversity is at risk (either from excessively frequent burning or from protracted fire-free intervals) as well as areas that should be scheduled for burning. The thresholds for fire frequency and season can be determined by plant species' sensitivity to elements of the fire regime. Significant shifts in any of these elements may eliminate some species (Van Wilgen \& Forsyth 1992). If these shifts manifest themselves over large areas, management action would be required to counter these trends. To support these assessments, fires that occur in the park are recorded in a geographic information system.

This paper provides the first comprehensive assessment of fire regimes in the park over the past four decades. The work aimed to determine whether the fire regimes were within acceptable limits in terms of their impact on biodiversity and if not, how, where and why they deviated from these limits. It also makes recommendations for the improvement of fire management in the park

\section{METHODS}

\section{Study area}

The Table Mountain National Park (centred at $34^{\circ} 00^{\prime} \mathrm{S}, 18^{\circ} 25^{\prime} \mathrm{E}$ ) was proclaimed in May 1998 and covers 26553 ha. The park includes most of the public undeveloped land bordered by the 
city of Cape Town and its southern suburbs. The park and the city are located on the Cape Peninsula, a $50 \times 10 \mathrm{~km}$ mountainous area with about $100 \mathrm{~km}$ of coastline. Elevations range from sea level to $1086 \mathrm{~m}$. Mean annual rainfall ranges from $1700 \mathrm{~mm}$ in the north to $400 \mathrm{~mm}$ in the south, and rain falls predominantly in the winter months (June to August). Sandstones and shales of the Cape Supergroup dominate the geology, and soils are generally sandy and low in nutrients. The predominant vegetation is fynbos, a fire-prone shrubland covering 22906 ha of the park. Renosterveld (a low, grassy shrubland) occurs on shale areas and covers 828 ha of the park; this vegetation type is also fire prone. Finally, well-developed Afromontane forests covering $\sim 1000$ ha occur in sheltered areas; these tend to be fire free (Van Wilgen et al. 1990), although forest margins are scorched by fire from time to time. Further details of the area are provided by Cowling et al. (1996). The fire regime of the area is characterised by dry-season (summer) fires at intervals of between 10 and 20 years (Bond 1997)

\section{Compilation of a fire database}

Fires in the area that now constitutes the Table Mountain National Park have been recorded by earlier land management agencies for many years. Typical fire records included a mapped boundary of each fire, along with the dates on which the fire occurred. Most records were transferred to the National Park following proclamation of the park. We assembled these records and captured the boundaries of all fires $>1$ ha in a geographic information system. Records were checked for completeness, and a concerted effort was made to locate missing records. Newspaper reports, aerial photographs, satellite images and references to unmapped fires were all used to ensure that a comprehensive database was compiled. The earliest fire records were from the 1950s, but reasonably complete records were only available from 1970 onwards. For this reason, we restricted further analyses to the period between 1970 and May 2007.

\section{Fire return periods}

The mean fire return period was calculated as $R P=y /(b / a)$, where $R P$ is the return period in years, $b$ is the area of all fires recorded over $y$ years and $a$ is the area over which fires were recorded. We calculated this statistic for the area as a whole as well as for the three dominant vegetation types by overlaying fire records on a vegetation map, using a geographic information system. Return periods were also calculated by decade to establish whether any trends in fire frequency were evident.

The above method delivers a single estimate of the mean fire return period and does not provide insight into individual fire return intervals (the time between individual fires in the same area). Very short fire return intervals can eliminate obligate reseeding shrubs if their juvenile periods are longer than the fire return interval (Noble \& Slatyer 1980, Van Wilgen \& Forsyth 1992). In order to assess fire return intervals, we delimited areas of unique fire history by overlaying fire records for the park (De Klerk et al. 2007). Each polygon of unique fire history was characterised by a number of fire return intervals (except for polygons where no fires were recorded or where only one fire was recorded). We examined the fire record for the occurrence of short fire return intervals ( $\leq$ six years) for two separate periods. Intervals of $\leq$ six years were chosen as this approximates the age at which the slower-growing obligate reseeding plants mature. Overlapping time periods (1970-1990 and 1985-2007) were used rather than successive periods (19701990 and 1991-2007) to ensure that short-interval fires that occurred between 1985 and 1990 would be identified.

\section{Fire season}

We calculated the total area burnt in different seasons for each year on the data record. The seasons were summer (NovemberFebruary inclusive); autumn (March-April inclusive); winter (May-August inclusive); and spring (September and October). We grouped the annual estimates of the occurrence of fires in different seasons into the periods 1970-1988 and 1989-2007, for comparative purposes.

\section{Cause of fires}

Fire records included, where available, the cause of the fire. The main causes of fires included fires of human origin (divided into prescribed burns and a range of other causes including arson, escaped barbecue fires, flares, power lines and so on), fires caused by lightning or falling rocks and fires of unknown origin.

\section{Fire size distribution and fire weather}

Fire size may be important for a number of ecological reasons (for example in terms of the relative proportion of 'edge effects' or the distances that must be covered by species reliant on dispersal for recolonising burntsites). Wealso wished to examine the relationship between fire size and fire weather. The size of individual fires was examined with a view to determining the proportion of area burnt in fires of different sizes. We also examined the fire record in terms of fire size distribution for the periods 1970-1988 and 1989-2007 to establish whether or not these proportions were changing over time.

We obtained daily weather data from a recording weather station at Cape Town International Airport $\left(33^{\circ} 58^{\prime} \mathrm{S}, 18^{\circ} 36^{\prime} \mathrm{E}\right)$ for the period 1970 to 2007 and used the McArthur Forest Fire Danger Index (Noble et al. 1980) to calculate daily indices of fire danger. The data used included daily maximum temperature and minimum relative humidity, wind speed, the time since the last rain fell and moisture deficit to estimate a fire danger index (FDI). FDI values of $0-5$ are considered low, 5-12 moderate, 13- 24 high, $25-50$ very high and > 50 extreme.

\section{RESULTS}

\section{Fire database}

A total of 373 fires $>1$ ha, covering 45757 ha, were recorded between 1970 and 2007. While some fires could have been overlooked, it is not possible to estimate how large this potential error would be. In addition, not every fire record was complete. Not all fire records were accompanied by a full date (day, month and year), and fires covering $19.7 \%$ of the total area burnt were associated with a particular year only. For these fires, the season of burning was not known, and it was not possible to associate them with weather conditions on the day of the fire. The causes of fires were also incompletely recorded, and 244 of the 373 fires were of unknown origin. These fires were assumed to be unplanned fires, as the origin of prescribed fires would have been known.

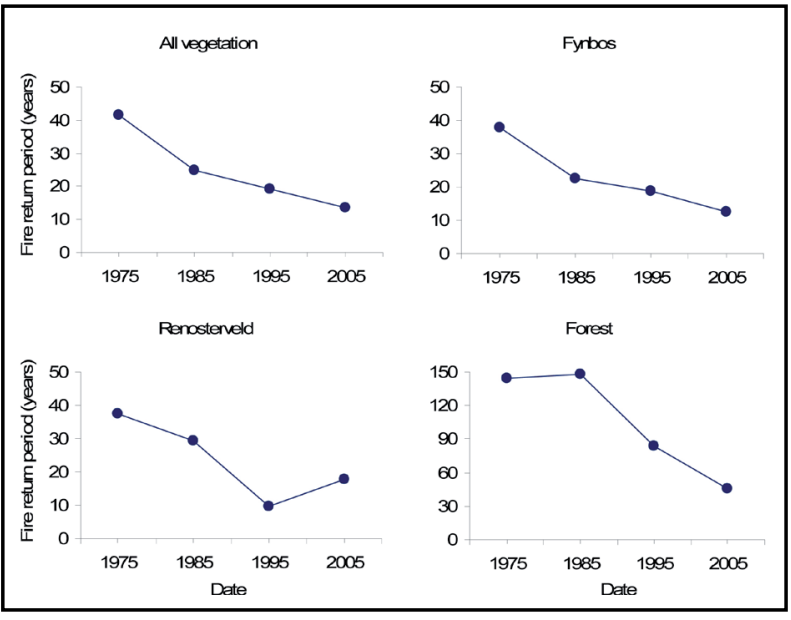

FIGURE 1

Mean fire return periods per decade in the Table Mountain National Park and in three component vegetation types. Note the difference in scale for forest vegetation. 


\section{Fire return periods}

The mean fire return period for the whole area between 1970 and 2007 was 22 years. Mean fire return periods declined in each decade of the fire record (Fig. 1). In fynbos vegetation, mean fire return periods declined by 18.1 years from 31.6 years in the 1970s to 13.5 years between 2000 and 2007. Equivalent estimates for renosterveld and forest are 37.4 to 17.7 years and 144.6 to 45.6 years respectively (Fig. 1).

The incidence of short-interval ( $\leq$ six yrs) fires also increased significantly from the first half of the data record to the second half (Table 1). The extent of these frequently burnt areas was four times greater between 1985 and 2007 than it was between 1970 and 1990 in fynbos vegetation (Fig. 2). Similarly, frequently burnt areas were five times more extensive in renosterveld.

Fire season

Most of the area $(90.5 \%)$ for which fire season was recorded burnt in summer or autumn (Fig. 3). The total area burnt during the first half of the data record was less than in the second half, and the proportion of fires burnt in summer and autumn increased from 86 to $92 \%$ between these two periods. A shift away from the practice of prescribed burning in winter and spring (when weather conditions were safer) to autumn could have contributed to this difference. The shift came about with the recognition that prescribed burns in winter and spring would have detrimental effects on the vegetation (Van Wilgen, Bond \& Richardson 1992). Fires in summer and autumn are regarded as optimal for the health of fynbos ecosystems (Van Wilgen, Bond \& Richardson 1992), while the occurrence of a smaller proportion of fires in other seasons is probably acceptable (Van Wilgen et al. 1994). From this, we conclude that the historic seasonal distribution of fires within the park should not be a cause for concern.

\section{Cause of fires}

The total area burnt in 373 fires on record was 45757 ha. There were 45 prescribed fires on record, and these burnt 6661 ha; a further 3164 ha was burnt in 16 prescribed fires that escaped (and burnt a larger area than intended). Prescribed burning thus accounted for only 9825 ha (21\% of the total area burnt), some of which was unintentional; thus most (> 80\%) of the area burnt in wildfires. Fires of unknown origin (244 fires) burnt 29118 ha or $63 \%$ of the area burnt in all fires. Six fires were attributed to natural causes (lightning, five fires and falling rocks, one fire), and these burnt 540 ha or $1 \%$ of the area.

TABLE 1

Areas of three vegetation types subjected to at least one short-interval ( $\leq$ six yrs) fire during two time periods in the Table Mountain National Park

\begin{tabular}{lllc}
\hline \multirow{2}{*}{ VEgETATION TYPE } & AREA COVERED BY VEGETATION TYPE (HA) & PROPORTION (\%) SUBJECTED TO SHORT-INTERVAL FIRE & $\mathbf{1 9 8 5 - 2 0 0 7}$ \\
\hline Fynbos & & $\mathbf{1 9 7 0 - 1 9 9 0}$ & 17.3 \\
Renosterveld & 22906 & 4.6 & 29.2 \\
Forest & 828 & 5.6 & 0.6 \\
\hline
\end{tabular}

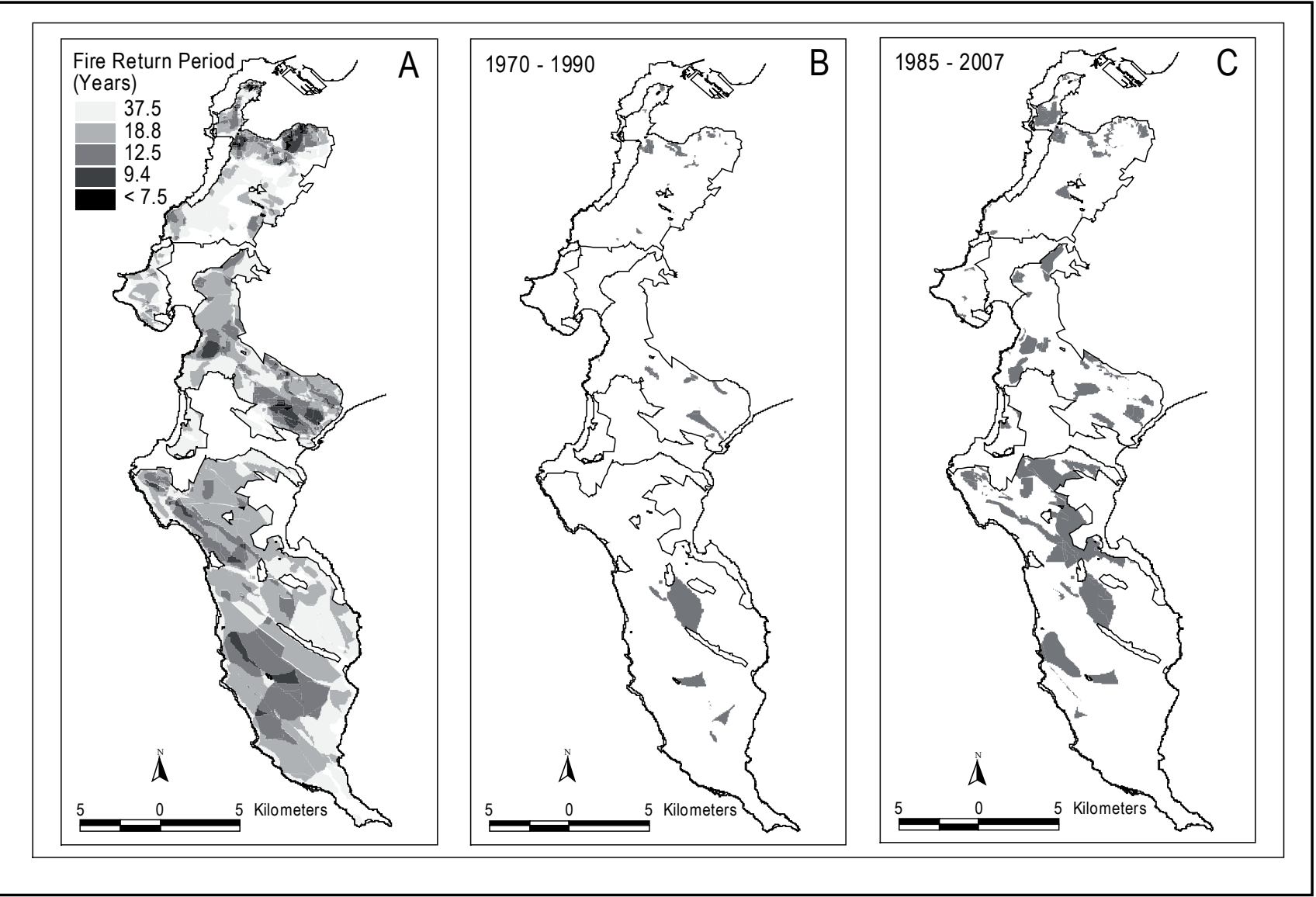

FIGURE 2

Fire return periods in the Table Mountain National Park. A = mean fire return periods based on all fires between 1970 and 2007. Note that unshaded areas within the park boundary did not burn (i.e. mean fire return period was $>37.5$ years), while unshaded areas outside of the park boundary were not included in the analysis. $\mathrm{B}=$ the spatial occurrence of short ( $\leq$ six yrs) fire return periods between 1970 and $1990 . \mathrm{C}=$ the spatial occurrence of short ( $\leq$ six yrs) fire return periods between 1985 and 2007. 


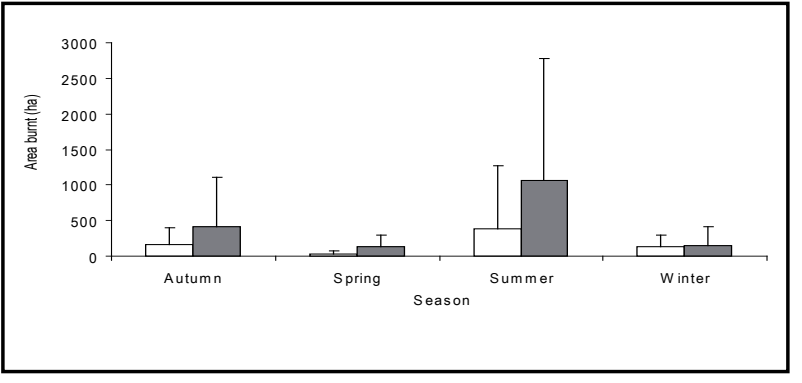

FIGURE 3

Mean annual area burnt in different seasons in all vegetation types in the Table Mountain National Park in two time periods (unshaded bars $=1970-1988$; shaded bars $=1989-2007$ ). Bars are standard deviations from the mean.

\section{Fire size}

Large numbers of small fires occurred in the Table Mountain National Park, but they burnt a relatively small area; on the other hand, a relatively small number of large fires burnt most of the area (Fig. 4). The two biggest fires on record (3 363 and 3204 ha respectively) both started on the same day (16 January 2000). Of the 373 fires on record, only 8 were over 1000 ha, and the 40 fires $>300$ ha burnt $75 \%$ of the area. On the other hand, 216 fires were $<25$ ha but burnt only $3.4 \%$ of the area. The distribution of fire sizes did not differ for the two periods compared, suggesting that fire size distribution is stable (Fig. 4).

\section{Fire weather}

The analysis of fire weather data and associated fire size revealed that fires in the park can take place under a relatively wide range of weather conditions, including conditions of low fire danger (Fig. 5). However, larger fires (>1000 ha) only occurred when the fire danger index was in or above the high category, and the two largest fires on record occurred when the index was in the very high category (Fig. 5). Unfortunately, the complete dates of many of the large fires were not recorded, and these fires are not depicted in Fig. 5 (9 out of the 16 largest fires on record, which ranged from 723 to 3363 ha, did not have full dates). The point should also be made that the Table Mountain National Park experiences relatively mild fire weather conditions when compared to fynbos areas further inland as a result of its proximity to the sea, which exercises a moderating effect on the weather (Van Wilgen 1984).

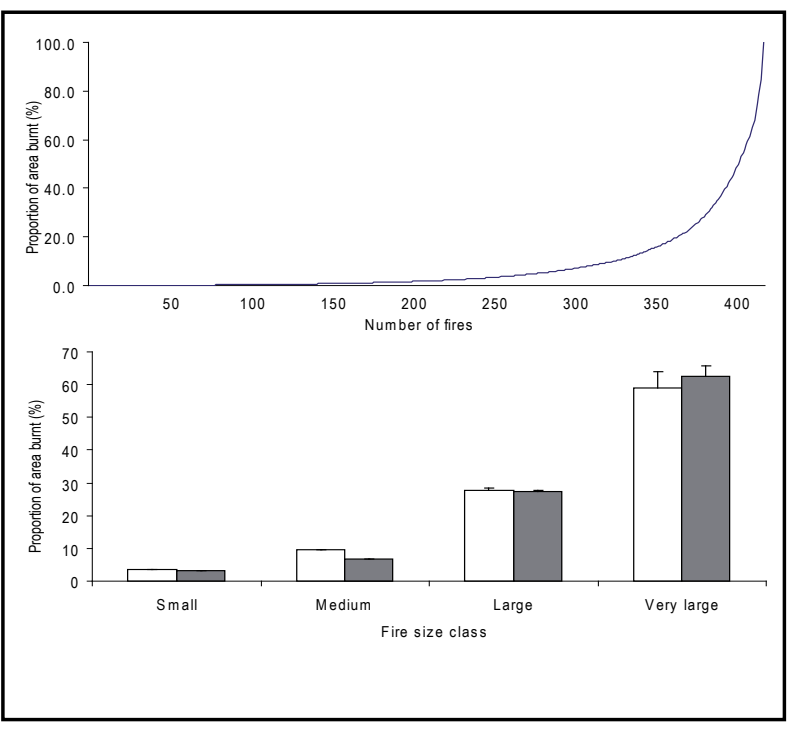

FIGURE 4

The relationship between fire size and area burnt in the Table Mountain National Park between 1970 and 2007 (upper figure). The proportion of the area burnt in fires of different sizes did not (uppe over time (lower figure). Size classes are small of different sizes did not change over time (lower figure). Size classes are small Un respectively. Bars are one standard deviation from the mean.

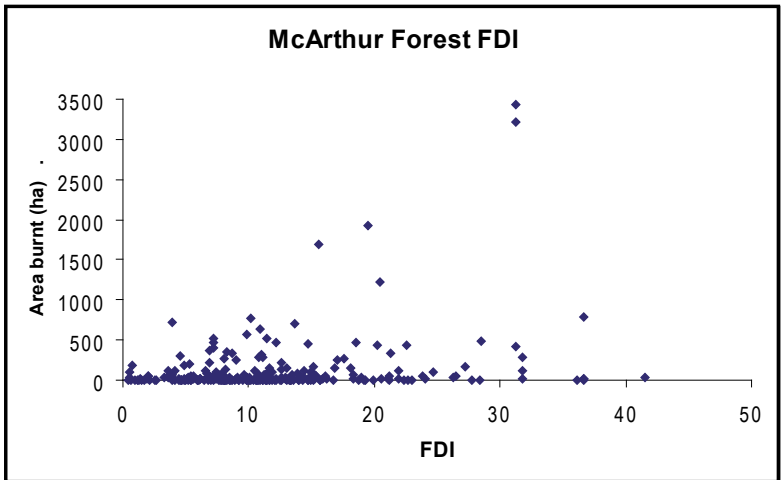

FIGURE 5

The fire weather conditions (as measured by the McArthur Forest Fire Danger Index, FDI) associated with fires of different sizes in the Table Mountain National Park between 1970 and 2007.

\section{DISCUSSION}

\section{History of prescribed burning in the park}

Prescribed burning as a land management practice was introduced to most fynbos conservation areas in 1970 (Bands 1977). Although prescribed burning was accepted as a conservation practice by some land management agencies on the Cape Peninsula in the 1970s and 1980s, the execution of prescribed fires proved problematic due to public resistance to the practice (Van Wilgen 1996). By 1996, only 3 out of 10 public land owners, managing just over $30 \%$ of the undeveloped land on the Peninsula, had adopted the use of prescribed burning (Van Wilgen 1996). The proclamation of the park in 1998 was followed in 2000 by the formal acceptance of a unified fire management plan, recognising the need for occasional prescribed burning (Forsyth et al. 2000). The largest fires on record occurred shortly after this in January 2001. These fires destroyed 14 houses and necessitated the temporary evacuation of many residents, both reducing the immediate need for further burning and hardening public attitudes towards fire. As a result, almost no large prescribed burns were subsequently conducted despite the revised policy. In 2007, a prescribed burn was initiated in the south of the park in an area that had not been burnt for some time; this fire escaped and burnt a larger area than had been planned, resulting in further criticism of the practice. Thus, despite overwhelming scientific support for prescribed burning to rejuvenate fire-adapted vegetation and as a vital component of invasive alien plant control, broader public support is not universal. Ongoing public awareness programmes will be needed to counter some of this criticism if prescribed burning is to take its place as a useful conservation management practice.

\section{Increases in short-interval fires}

Short-interval fires in recent years were fairly widespread across the park (Fig. 2). The increase in short-interval fires identified in this study is almost certainly attributable to increased ignition sources resulting from increases in human population. The relaxation of rigid influx controls under the apartheid government in the 1980s, which accelerated economic growth over the past decade, and increasing immigration into urban areas have all contributed to the rapid growth of the human population in the area. Increases in human population have been shown to be correlated with increases in fire frequency in Californian chaparral ecosystems (Keeley et al. 1999, Keeley \& Fotheringham 2001), and it appears that similar trends may now be occurring in the Table Mountain National Park.

\section{Ecological effects of fire in fynbos}

Managers charged with conserving biodiversity in firedependent ecosystems need to assess whether fire regimes remain within acceptable limits. The elements of the fire 
regime normally assessed with respect to fynbos relate to fire frequency and fire season (Van Wilgen \& Scott 2001). In terms of fire season, managers of fynbos ecosystems should seek to keep the majority ( $>80-90 \%$ ) of fires in summer or autumn to avoid negative impacts (Van Wilgen, Bond \& Richardson 1992). As most (>90\%) fires occur at this time of the year, there is no indication that this aspect should be a cause for concern in the Table Mountain National Park. Long fire-free intervals (> 35 years) may also be a cause for concern as they lead to senescence (Bond 1980, Van Wilgen 1982). Over the past 37 years, only $12.7 \%$ of the Peninsula has remained fire free and about a fifth of this was in fire-independent forest or coastal vegetation. In this regard, therefore, a lack of fire does not present a serious cause for concern. Nonetheless, areas that remain fire free for long periods should be identified and monitored to ensure that important fire-dependent species are not affected. On the other hand, the significant increase in fire frequency and the accompanying increase in areas subjected to short-interval fires are causes for concern.

Most species in fynbos vegetation are resilient to a wide range of fire return intervals. For example, Van Wilgen and Forsyth (1992) established the regeneration strategies of 210 co-occurring fynbos species; of these, most were able to resprout after fire, and only 29 species were classified as obligate seeders (species that have their growth cycle terminated prematurely by fire and are unable to sprout). Large, serotinous shrubs with relatively long juvenile periods are an important component among obligate seeders. These species, typically in the family Proteaceae, are killed by fire and rely on canopy-stored seed for regeneration (Bond, Vlok \& Viviers 1984). While only a small proportion of the total number of species fall into this category (Van Wilgen \& Forsyth 1992), they can be the dominant component (in terms of cover and biomass) of the vegetation. Short intervals between fires (less than the juvenile periods) can eliminate these species from the vegetation and cause dramatic structural changes (Van Wilgen 1982). As a result, they are usually the species that are used to determine acceptable fire return intervals (Van Wilgen, Bond \& Richardson 1992). For example, Kruger and Lamb (1979) proposed that the minimum interval between prescribed fires in fynbos should be equivalent to the time needed for at least $50 \%$ of the individuals in a population of the slowest-maturing of the obligate reseeding species to have flowered and developed seed for at least three successive seasons. Application of this rule normally suggests a minimum period of between 10-12 years between fires, and this is currently not being met in over $10 \%$ of the park (Table 1).

There have been several detailed studies on the responses of fynbos to fire in the Table Mountain National Park (Bond, Le Roux \& Erntzen 1990, Cowling \& Gxaba 1990, Moll \& Gubb 1981, Thuiller et al. 2007, Yeaton \& Bond 1991). Of the 40 extant species of Proteaceae in the park, at least 9 (in the genera Protea, Leucadendron, Leucospermum and Mimites) are killed by fire (Protea Atlas 2007) and rely on seed for regeneration. The juvenile periods of these species are not accurately known but are presumably similar to species of Proteaceae elsewhere (i.e. three to six years) (Van Wilgen \& Forsyth 1992). Comparison of distribution data (Protea Atlas 2007) with the extent of shortinterval fires (Fig. 2) shows that at least five of these (including one endemic) are at risk from frequent burning. In addition, the 34 species of rare or threatened Erica (including 29 endemics) (Golding 2002, Richardson et al. 1996) that occur in the park are likely to be adversely affected by frequent burning, although detailed data on their distribution and ecology are not available. Finally, the shrub Staavia dodii (also endemic) is known to be at risk (Moll \& Gubb 1981), although its range is currently outside of the areas affected by short-interval fires.

There is evidence that variation in fire regimes is necessary to maintain plant diversity in the landscape (Thuiller et al. 2007). Variation in the intervals between fires, in fire season or in fire intensity will induce variation in the density of overstorey shrubs (for example Leucadendrom laureolum), and this variation is in turn associated with the maintenance of diversity in understorey species (Cowling \& Gxaba 1990, Thuiller et al. 2007). Thuiller et al. (2007) concluded that recurrent fires will safeguard plant populations against extinction by ensuring stable co-existence over time, despite localised extirpation by individual fires. This finding was based on two surveys of plant composition on fixed sites 30 years apart. These sites were, however, in the southern part of the park that had not been subjected to repeated frequent burning (Fig. 2). It is well known that repeated frequent burning can eliminate important overstorey shrubs in fynbos (Van Wilgen 1981, 1982). While we accept that variation in fire regimes is acceptable and even necessary, there are limits beyond which elements of the vegetation may well suffer.

\section{Ecological effects of fire in non-fynbos vegetation}

Fire frequencies and the occurrence of short-interval fires have also increased in renosterveld vegetation over the past few decades. This is not expected to have serious consequences for species diversity, but data are lacking to test this hypothesis. While the fire regimes in renosterveld vegetation have been poorly studied (Van Wilgen 1987), fire return intervals are assumed to be shorter than those in fynbos due to the dominance of species with short maturation times (Boucher 1983). At present there is no evidence that increases in fire frequency in renosterveld are a cause for concern.

The apparent increase in fire frequency (Fig. 1) in forests is probably not a cause for concern. Most forest vegetation has remained fire free (Table 1), but where fires do occur, they appear to be getting more frequent (although not as frequent as in fynbos). The vegetation mapped as forest by Cowling et al. (1996) included areas of scrub thicket with a potential to develop into forest. These authors recognised that prolonged ('centuries-long') fire-free periods would be needed to allow forests to develop on these sites. Afromontane forests persist in fire refugia in fynbos vegetation, and while their expansion into surrounding areas would be possible under current climates, this is limited by recurrent fires (Manders \& Richardson 1992). The apparent increase in fire frequency in forest vegetation is probably a result of fires in scrub thicket as well as the fact that areas recorded as being burnt would contain forest patches that in fact did not burn. At present there is no evidence that fires are causing forest patches to shrink.

\section{Comparison to other areas}

The fire management situation in the Table Mountain National Park bears strong similarities to some other areas in fireprone Mediterranean climates. For example, the Santa Monica National Park (Los Angeles, California) and the Blue Mountain National Park (Sydney, Australia) are both important fire-prone conservation areas within an urban setting. As with the Table Mountain situation, both have a substantial urban-wildland interface, and both are subjected to periodic wildfires that cause substantial damage to property (Bradstock et al. 1998, Keeley \& Fotheringham 2006). In the Los Angeles situation, fire frequency has been shown to be increasing over the past century, and this is linked to increasing human populations, providing increasing sources of ignition (Keeley \& Fotheringham 2001). This problem now appears to be manifesting itself in the Table Mountain case. In both cases, increasing fire frequency will impact on the survival and post-fire recovery of dominant shrubs, and in both cases invasive alien plants are able to take the place of dominant indigenous shrubs, with negative consequences for the conservation of biodiversity and ecosystem services. In the Californian case, the alien species are grasses, which promote more frequent fire (Keeley, Keeley \& Fotheringham 2005). In the Table Mountain case, they are largely alien trees and shrubs, which increase fire intensity and erosion after fire (Van Wilgen \& Scott 2001). Despite the similarities, the scale of the fire problem is orders of magnitude larger in Los Angeles 
or Sydney when compared to the Table Mountain area. For example, the 2003 fires in Los Angeles burnt 364000 ha and destroyed 3361 homes (Keeley \& Fotheringham 2006). The fires in December 2001 in Sydney burnt 250000 ha and destroyed 109 homes (Shakesby et al. 2003). In contrast, the fires in January 2000 in the Table Mountain National Park (the worst by far on record) only burnt 7000 ha and destroyed 14 homes (Van Wilgen \& Scott 2001). These differences could be attributed to higher fuel loads and more severe fire weather in Australia and California than in the Table Mountain area.

\section{Fire and conservation in urban-dominated landscapes}

As a result of the establishment of a comprehensive spatial database on fires, managers in the Table Mountain National Park should now be able to make better and more informed decisions about fire management. The key will be to maintain and regularly update the database and to analyse it periodically. The existence of relevant analyses will enable managers to identify areas of concern (such as areas that have been subjected to repeated, short-interval fires) and to take appropriate action. It will also provide them with a defensible basis for making decisions about the ignition of prescribed burns or the tolerance of wildfires. Both of these will usually elicit comment and possibly criticism from interested and affected parties. It is also important that managers ensure that fire records are complete so that the best possible information can be used to support management decisions. We found, for example, that several fire records were incomplete in that the dates, durations and causes were not always consistently recorded, and this will weaken any subsequent analysis.

Appropriate responses to human-caused increases in fire frequency would be to increase both vigilance and public awareness in areas close to human habitation, to improve the chances of preventing further ignitions and/or the early identification and rapid containment of fires should they occur in such priority areas. Secondly, in areas where short-interval fires have been found to occur, it would be prudent to conduct surveys of plant regeneration as soon as possible following fire and to consider, for example, the reintroduction of important plant species should they be found to have been eliminated from the area. Finally, the situation with regard to the regeneration and spread of invasive alien plants in areas subjected to higherthan-normal fire frequencies should be carefully managed. It is often the case that invasive alien species are superior competitors in the face of fire regimes that differ from those under which the indigenous biota evolved, and this represents a significant ongoing threat to the conservation of the park's unique flora.

\section{ACKNOWLEDGEMENTS}

This work was jointly funded by South African National Parks, Cape Nature and the South African Council for Scientific and Industrial Research. We thank South African National Parks for access to fire records and Lucille Schonegevel and Patrick O'Farrell for assistance with data capture and processing.

\section{REFERENCES}

Bands, D.P. 1977. Prescribed burning in the Cape fynbos. In: Mooney, H.A. \& Conrad, C.E. (Eds.). Proceedings of the symposium on the environmental consequences of fire and fuel management in mediterranean ecosystems. Pp 245-256. USDA Forest Service, General Technical Report WO-3.

Bond, W.J. 1980. Fire and senescent fynbos in the Swartberg, Southern Cape. South African Forestry Journal 114: 68-74.

Bond, W.J. 1997. Fire. In: Cowling, R.M., Richardson, D.M. \& Pierce, S.M. (Eds.). The vegetation of southern Africa. Pp 421446. Cambridge: Cambridge University Press.
Bond, W.J., Le Roux, D. \& Erntzen, R. 1990. Fire intensity and regeneration of myrmecochorous Proteaceae. South African Journal of Botany 56: 326-331.

Bond, W.J., Vlok, J. \& Viviers, M. 1984. Variation in seedling recruitment of Cape Proteaceae after fire. Journal of Ecology 72: 209-221.

Boucher, C. 1983. Floristic and structural features of the coastal foreland vegetation south of the Berg River, Western Cape Province, South Africa. Bothalia 14: 669-674.

Bradstock, R.A., Gill, A.M., Kenny, B.J. \& J. Scott, J. 1998. Bushfire risk at the urban interface estimated from historical weather records: consequences for the use of prescribed fire in the Sydney region of south-eastern Australia. Journal of Environmental Management 52: 259-271.

Cowling, R.M. \& Gxaba, T. 1990. Effects of a fynbos overstorey shrub on understorey community structure: implications for the maintenance of community-wide species richness. South African Journal of Ecology 1: 1-7.

Cowling, R.M., Macdonald, I.A.W. \& Simmons, M.T. 1996. The Cape Peninsula, South Africa: physiographical, biological and historical background to an extraordinary hot-spot of biodiversity. Biodiversity and Conservation 5: 527-550.

De Klerk, H., Schutte-Vlok, A., Vlok, J., Shaw, K., Palmer, G., Martens, C., Viljoen, P., Marshall, T., Van Ross, G., Forsyth, A.T., Wessels, N., Geldenhuys, D., Wolfaardt, A. \& Kirkwood, D. 2007. Ecological fire monitoring manual. Stellenbosch: Cape Nature Scientific Services.

Forsyth, G.G., Van Wilgen, B.W., Ruddock, G., Nel, J.L., Le Maitre, D.C., Smith, C., Cullinan, C., \& Chapman, R.A. 2000. A fire management plan for the Cape Peninsula National Park. Report no. ENV-S-C 2000-111, CSIR, Stellenbosch.

Golding, J. 2002. Southern African plant red data lists. National Botanical Institute, Pretoria.

Keeley, J.E. \& Fotheringham, C.J. 2001. Historic fire regime in southern California shrublands. Conservation Biology 15: 1536-1548.

Keeley, J.E. \& Fotheringham, C.J. 2006. Wildfire management on a human-dominated landscape: California chaparral wildfires. In: Wuerthner, G. (Ed.). The wildfire reader: a century of failed forest policy. Pp 116-131. Washington: Island Press.

Keeley, J.E., Fotheringham, C.J. \& Morais, M. 1999. Re-examining fire suppression impacts on brushland fire regimes. Science 284: 1829-1832.

Keeley, J.E., Keeley, M.B. \& Fotheringham, C.J. 2005. Alien plant dynamics following fire in mediterranean-climate California shrublands. Ecological Applications 15: 2109-2125.

Kruger, F.J. \& lamb, A.J. 1979. Conservation of the Kogelberg State Forest. Preliminary assessment of the effects of management from 1967 to 1978. Report 79-02, Jonkershoek Forestry Research Centre, Stellenbosch.

Manders, P.T. \& Richardson, D.M. 1992. Is fynbos a stage in succession to forest? Analysis of the perceived ecological distinction between two communities. In: Van Wilgen, B.W., Richardson, D.M., Kruger, F.J. \& Van Hensbergen, H.J. (Eds.). Fire in South African mountain fynbos: species, community and ecosystem response in Swartboskloof. Pp 81-107. Heidelberg: Springer Verlag.

Moll, E.J. \& Gubb, A.A. 1981. Aspects of the ecology of Staavia dodii in the South Western Cape of South Africa. In: H. Synge. (Ed.). The biological aspects of rare plant conservation. Pp 331-342. New York: John Wiley \& Sons.

Noble, I.R. \& Slatyer, R.O. 1980. The use of vital attributes to predict successional changes in plant communities subject to recurrent disturbances. Vegetatio 43: 5-21.

Noble, I.R., Gill, A.M \& Bary, G.A.V. 1980. McArthur's fire danger meters expressed as equations. Austral Ecology 5: 201-203.

Protea Atlas. 2007. (http://protea.worldonline.co.za/idm_ cp.htm). Maintained by Rebelo A., South African National Biodiversity Institute, Kirstenbosch, South Africa. (Accessed 26 August 2007).

Richardson, D.M., Van Wilgen, B.W., Higgins, S.I., Trinder-Smith, T.H., Cowling, R.M. \& McKelly, D.H. 1996. Current and 
future threats to plant biodiversity on the Cape Peninsula, South Africa. Biodiversity and Conservation 5: 607-647.

Richardson, D.M., Van Wilgen, B.W., Le Maitre, D.C., Higgins, K.B., \& Forsyth, G.G. 1994. A computer-based system for fire management in the mountains of the Cape Province, South Africa. International Journal of Wildland Fire 4: 17-32.

Shakesby, R.A., Chafer, C.J., Doerr, S.H, Blake, W.H., Wallbrink, P., Humphreys, G.S. \& Harrington, B.A. 2003. Fire severity, water repellency characteristicsand hydrogeomorphological changes following the Christmas 2001 Sydney forest fires. Australian Geographer 34: 147-175.

Thuiller, W., Slingsby, J.A., Privett, S.D.J. \& Cowling, R.M. 2007. Stochastic species turnover and stable coexistence in a species-rich, fire-prone plant community. Plos ONE 2(9): doi:10.1371/journal.pone.0000938.

Van Wilgen B.W., Bond, W.J. \& Richardson, D.M. 1992. Ecosystem management. In: Cowling, R.M. (Ed.). The ecology of fynbos: nutrients, fire and diversity. Pp 345-371. Cape Town: Oxford University Press.

Van Wilgen, B.W. \& Forsyth, G.G. 1992. Regeneration strategies in fynbos plants and their influence on the stability of community boundaries after fire. In: Van Wilgen, B.W., Richardson, D.M., Kruger, F.J. \& Van Hensbergen, H.J. (Eds.). Fire in South African mountain fynbos: species, community and ecosystem response in Swartboskloof. Pp 54-80. Heidelberg: Springer Verlag.

Van Wilgen, B.W. \& Scott, D.F. 2001. Managing fires on the Cape Peninsula: dealing with the inevitable. Journal of Mediterranean Ecology 2: 197-208.

Van Wilgen, B.W. 1981. Some effects of fire frequency on fynbos plant community composition and structure at Jonkershoek, Stellenbosch. South African Forestry Journal 118: 42-55.
Van Wilgen, B.W. 1984. Fire climates in the southern and western Cape Province and their potential use in fire control and management. South African Journal of Science 80: 358-362.

Van Wilgen, B.W. 1996. Management of the natural ecosystems of the Cape Peninsula: current status and future prospects. Biodiversity and Conservation 5: 671-684.

Van Wilgen, B.W. 1982. Some effects of post fire age on the above ground biomass of fynbos (macchia) vegetation in South Africa. Journal of Ecology 70: 217-225.

Van Wilgen, B.W. 1987. Fire regimes in the fynbos biome. In: Cowling, R.M., Le Maitre, D.C., McKenzie, B., Prys-Jones, R.P. \& Van Wilgen, B.W. (Eds.). Disturbance and the dynamics of fynbos biome communities. Pp 6-14. South African National Scientific Programmes Report No. 135. Pretoria: CSIR.

Van Wilgen, B.W., Higgins, K.B. \& Bellstedt, D.U. 1990. The role of vegetation structure and fuel chemistry in excluding fire from forest patches in the fire-prone fynbos shrublands of South Africa. Journal of Ecology 78: 210-222.

Van Wilgen, B.W., Richardson, D.M. \& Seydack, A. 1994. Managing fynbos for biodiversity: constraints and options in a fire-prone environment. South African Journal of Science 90: 322-329.

Van Wilgen, B.W., Richardson, D.M., Kruger, F.J. \& Van Hensbergen, H.J. 1992. Fire in South African mountain fynbos: species, community and ecosystem response in Swartboskloof. Heidelberg: Springer Verlag.

Yeaton, R.I. \& Bond, W.J. 1991. Competition between two shrub species: dispersal differences and fire promote coexistence. American Naturalist 138: 328-341. 